\title{
複合吹錬転炉の治金反応特性
}

\section{Metallurgical Characteristics of Combined Blowing Converter}

Masahiro KAWAKAMI and Koin ITO

\section{1. 緒言}

複合吹錬転炬には，各社各様の名前が付けられている が，底吹きガスの種類と流量に多少の差異が認められる ものの，ほほ同様の治金特性をねらったものである，公 表されている各社のプロセス名, および, 代表的な炉容 量, 吹込みガスの種類と流量をまとめて, Table 1 に示 す. 転炉の複合吹鍊化に至る各社の経緯は本特集号の前 報にまとめられているので,ここでは, 複合吹錬化によっ て治金反応特性がどう変化したかを，LD 転炉および底 吹き転炉と比較しつつ, 解説する。 なお，範囲としては， 通常スラグ吹鍊と予備処理溶銑を用いた少量スラグ吹鍊 までとした，クロム鈗石，マンガン鉱石，鉄鉱石などの 溶融還元およびスクラップ溶解については, 本特集号の 主題でもあるので，他の論文に任せることとした．

\section{2. 複合吹鍊化の必然性}

梅田らは LD 転炉と底吹き転炉を比較することによ り, 前者の短所を( 1 )精錬末期に鋼浴の䁌拌が低下し,

Table 1. Examples of combined blow converter at Japanese steel makers.

\begin{tabular}{|c|c|c|c|c|c|}
\hline & Name & Capacity & $\begin{array}{l}\text { Kind of bottom } \\
\text { blown gas }\end{array}$ & $\begin{array}{c}\text { Flow rate } \\
\left(\mathrm{Nm}^{3} / \mathrm{min} \cdot \mathrm{t}\right)\end{array}$ & Ref. \\
\hline NSC & $\begin{array}{l}\mathrm{LD}-\mathrm{AB} \\
\mathrm{LD}-\mathrm{OB}\end{array}$ & $\begin{array}{r}70 \mathrm{t} \\
70 \mathrm{t} \\
320 \mathrm{t} \\
\end{array}$ & $\begin{array}{l}\mathrm{Ar}, \mathrm{Ar}-\mathrm{O}_{2}-\mathrm{N}_{2} \\
\mathrm{O}_{2}-\mathrm{C}_{m} \mathrm{H}_{n} \\
\mathrm{O}_{2}-\mathrm{C}_{m} \mathrm{H}_{n}\end{array}$ & $\begin{array}{c}\sim 0.31 \\
0.24 \sim 0.48 \\
0.10 \sim 0.30\end{array}$ & $\begin{array}{l}\text { 1) } \\
\text { 1) } \\
\text { 2) }\end{array}$ \\
\hline NKK & NK-CB & $250 \mathrm{t}$ & $\mathrm{Ar}, \mathrm{CO}_{2}, \mathrm{~N}_{2}$ & $\sim 0.10$ & 3) \\
\hline Kawasaki & $\begin{array}{l}\text { K-BOP } \\
\text { LD-KGC }\end{array}$ & $\begin{array}{l}250 \mathrm{t} \\
180 \mathrm{t}\end{array}$ & $\begin{array}{l}\mathrm{O}_{2}-\mathrm{C}_{3} \mathrm{H}_{8} \\
\mathrm{CO}, \mathrm{Ar}, \mathrm{N}_{2}\end{array}$ & $\begin{array}{c}1.0 \sim 1.5 \\
0.005 \sim 0.2\end{array}$ & $\begin{array}{l}4) \\
5)\end{array}$ \\
\hline Sumitomo & STB & $250 \mathrm{t}$ & $\mathrm{Ar}, \mathrm{N}_{2}, \mathrm{CO}_{2}, \mathrm{O}_{2}$ & $0.02 \sim 0.29$ & 6) \\
\hline Kobe & LD-OTB & $\begin{array}{l}200 \mathrm{t} \\
240 \mathrm{t}\end{array}$ & $\begin{array}{l}\mathrm{Ar}, \mathrm{N}_{2} \\
\mathrm{CO}\end{array}$ & $0.03 \sim 0.10$ & $\begin{array}{l}\text { 7) } \\
8)\end{array}$ \\
\hline Nisshin & NSS & $185 \mathrm{t}$ & $\begin{array}{l}\mathrm{O}_{2}, \mathrm{LPG}, \mathrm{N}_{2} \\
\mathrm{Ar}, \mathrm{CO}_{2}, \mathrm{Air}\end{array}$ & $0.06 \sim 0.16$ & 9) \\
\hline
\end{tabular}

鉄の酸化ロスが増大する. ( 2)火点温度が極度に上昇し, 鉄の蒸発口スを助長する。（3)極低炭域の脱炭に難点が あり， $\mathrm{C}=0.03 \%$ が下限であるとまとめている ${ }^{6)}$. 成田 らは, LD 転炉の計算機制御を行うための検討の中で, 転炉内の $\mathrm{C}$ 含有量および温度の不均一性を実験により 確かめている ${ }^{10)}$. KAWAKAMI らは，LD 転炉操業の終点 において，鋼浴およびスラグ中の酸素ポテンシャルを測 定し，後者の方が約一桁大きいことを示した ${ }^{11)}$ 。この 他にも，鋼浴の攪拌強化により脱りんが促進されること

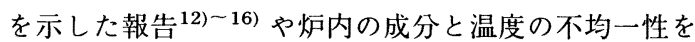
示した報告1718)もある。

一方，底吹き転炉では，鋼浴とスラグ間に酸素ポテン シャルの差が小さい ${ }^{19)}$ など炉内は比較的均一であると 考えられるものの ${ }^{20)},(1)$ 鋼浴の攪拌が過大で，スラ グ中の酸化鉄分が減少し脱りん不良を生ずる。（2）羽口 の冷却用として炭化水素系ガスを用いるため，鋼浴中の 水素が上昇する.（3)鉄分の酸化が少なく，また，冷却 ガスを使用するので，溶銑率が増加する．（4)炉底部羽 口周辺の耐火物の寿命が短いといった短所も指摘されて いる ${ }^{6)}$.このように, LD 転炉と底吹き転炉の短所を補い, 長所を活かすために，転炉の複合吹鍊技術が開発される に至ったと考えられる.

\section{3. 吹鍊中の成分挙動}

$175 \mathrm{t}$ 実機転炬における吹鍊中の成分挙動も発表され ているが21) 各吹錬の特徵を明らかにするため $2.5 \mathrm{t} の$ 試験転炉におけるデー夕6)を用いて，複合吹錬転炉の吹 鍊中の成分挙動を LD 転炉および底吹き転炉の場合と 比較する．LD転炉および底吹き転炉の場合の送酸速度 は複合吹鍊の場合と同じである。また，底吹き転炉では， 造滓材を酸素と共に底吹きした．Fig. 1 に Mn， P およ び T. Fe の変化を炭素含有量に対してプロットした。 吹鍊は図の右から左へ向かって進行する. Mn は, 吹錬 初期には, LD 転炉と同じ挙動を示すが, 末期には, 底

平成 2 年 3 月 30 日受付 (Received Mar. 30,1990)（依頼解説）

* 豊橋技術科学大学工学部教授 工博 (Faculty of Engineering, Toyohashi University of Technology, 1-1 Hibarigaoka Tempaku-cho Toyohashi 441)

Key words : combined blow converter; metallurgical characteristics ; bottom gas stirring ; decarburization ; dephosphorization; Mn reaction; Fe yield ; less slag blowing ; [C] [O] relation. 


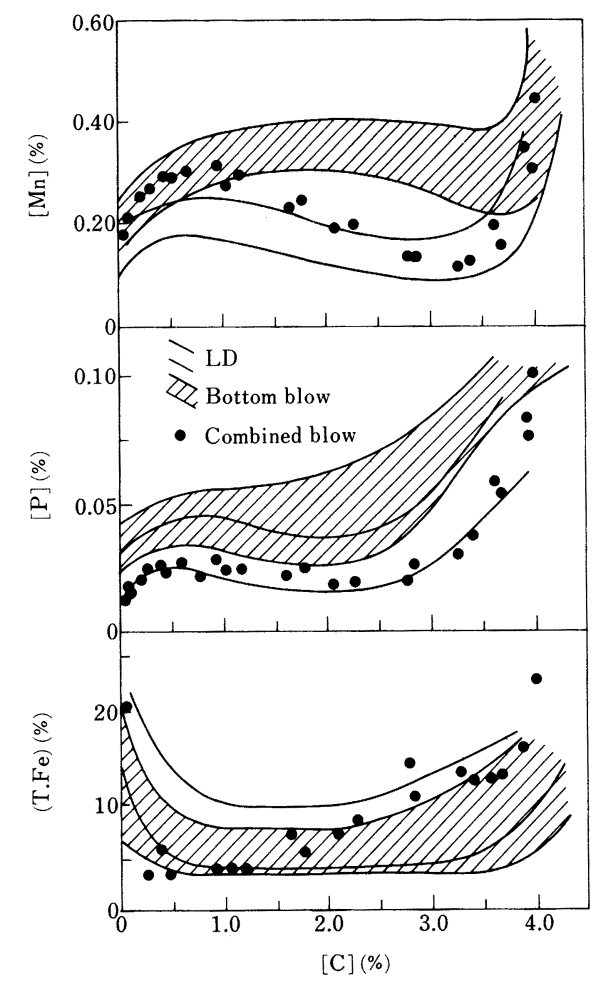

Fig. 1. Comparison of changes in $[\mathrm{Mn}],[\mathrm{P}]$ and ( T. Fe) during refining at $2.5 \mathrm{t} \mathrm{LD}$, bottom blow and combined blow converters (bottom blown $\mathrm{Ar}$ : $\left.0.42 \mathrm{Nm}^{3} / \mathrm{min} \cdot \mathrm{t}\right)^{6}$.

吹き転炉の挙動と一致し，LD 転炉と比べ高い值を示し た. $\mathrm{P} は ，$ 全吹錬期間を通して，LD 転炉とほほ同様の 挙動を示すが，末期には，むしろ低い值となった。 T. $\mathrm{Fe}$ は，初期には高く, LD 転炉とほほ同様の挙動を示 すが，末期には，底吹き転炉に一致する。この図より， 底吹き転炉の利点である高 $\mathrm{Mn}$ 歩留りと低 $\mathrm{T} . \mathrm{Fe}$ ，およ び LD 転炉の利点である高脱りん率の得られる可能性 が筧える。

\section{4. 吹止め時における成分挙動}

吹止め時における成分挙動については，甲斐らが $70 t$ 転炉を用い，Arまたは酸素を底吹きした複合吹鍊の場 合の結果をもとにまとめている1).

\section{$4 \cdot 1$ 溶鋼中 FreeO およびスラグ中 T. Fe の挙動}

吹止め時の FreeO を固体電解質で測定した. Fig. 2 に，全送酸量の約 $10 \%$ を底吹きした時の FreeO と吹

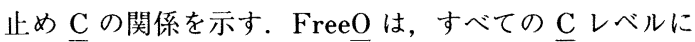
おいて，LD 転炉の実績值より低く，Q-BOP（底吹き 転炉）の報告值 ${ }^{18)}$ とほぼ一致した。また， [\% C ] $\geqq 0.10$ では, $P_{\mathrm{CO}}=1 \mathrm{~atm}$ との平衡值にほぼ対応するが,

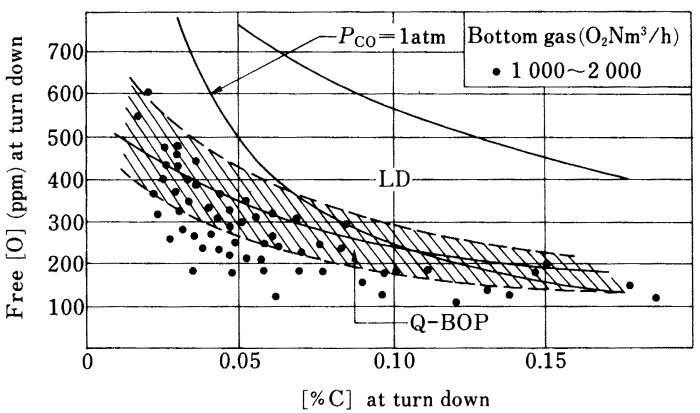

Fig. 2. Relation between $[\% \mathrm{C}]$ and Free [O] at turn down in the case of oxygen-bottom blowing : 70 t converter $^{1)}$.

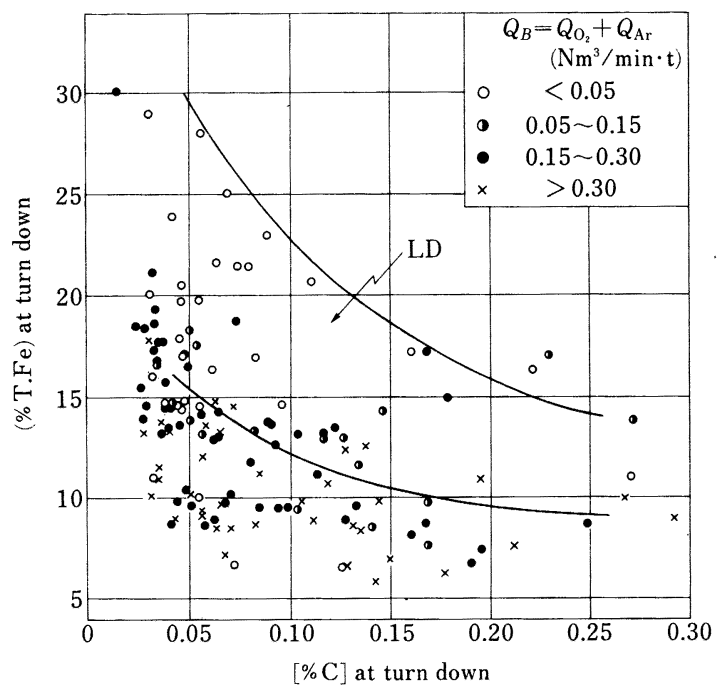

Fig. 3. Relation between [\%C] and (\%T.Fe) at turn down : $70 \mathrm{t}$ converter ${ }^{1)}$.

$[\% \mathrm{C}] \leqq 0.05$ では， $P_{\mathrm{CO}}=0.5 \mathrm{~atm}$ に相当する值に近く なり，低炭域ほど平衡すべき $P_{\mathrm{CO}}$ が小さくなる傾向で あった。

Fig. 3 には，Ar と酸素を底吹きした時の，スラグ中 $\mathrm{T} . \mathrm{Fe}$ と吹止め $\mathrm{C}$ の関係を示す. T. Fe は, 底吹きガ ス流量が $0.15 \mathrm{Nm}^{3} / \mathrm{min} \cdot \mathrm{t}$ 以上であれば, LD 転炉の実 績值を下まわり，特に，低炭域でも約 $10 \%$ の低い值と なっている. Fig. 4 には， $0.04 \leqq 0.06$ とほほ一定の $\mathrm{C}$ で, 溶鋼単位重量, 単位時間当たりの底吹きガス流量と T. Fe の関係を示す.このような低炭域では, T. Fe は, 吹込みガス流量に反比例して低下し，ガスの種類による 差異は認められなかった。 全送酸量の約 $90 \%$ を上吹き する複合吹鍊では，上吹き酸素ジェットによる攪挥効果 も無視できない. その効果を示す指標として，ジェット 


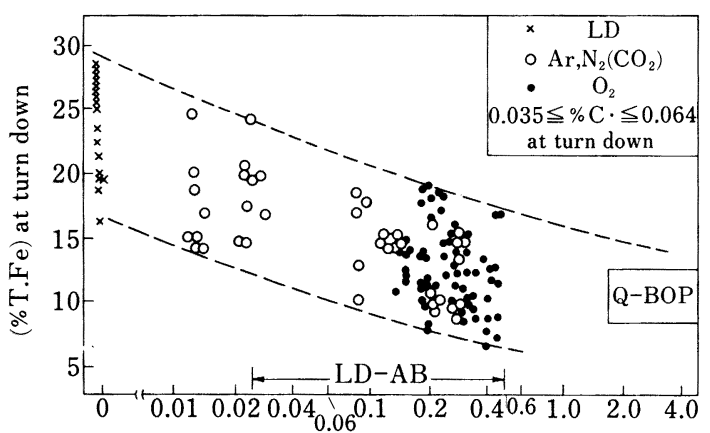

Bottom blowing gas flow rate $\left(Q_{\text {Inert }}+Q_{\mathrm{O}_{2}}\right)\left(\mathrm{Nm}^{3} / \mathrm{min} \cdot \mathrm{t}\right)$

Fig. 4. Relation between bottom gas flow rate and (\%T.Fe) in slag : $70 \mathrm{t}$ combined blow converter ${ }^{1)}$.

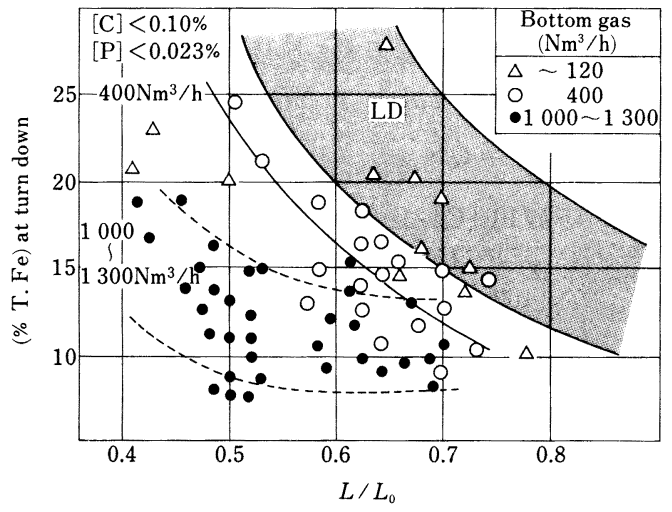

Fig. 5. Influence of the bottom gas flow rate on the relation between $L / L_{0}$ and $(\% \mathrm{~T} . \mathrm{Fe})$ at turn down : $70 \mathrm{t}$ combined blow converter ${ }^{1)}$.

により生成する鋼浴の準み深さ $L$ を鋼浴深さ $L_{0}$ で 割った $L / L_{0}$ を用いる. $L / L_{0}$ が大きければハードブ ロー，小さければソフトブローであることを意味する． 公知文献にある式を用いて $L / L_{0}$ を計算し, 吹止め $\mathrm{C}$ と $\mathrm{P}$ が $0.03 \leqq[\% \mathrm{C}] \leqq 0.10,[\% \mathrm{P}] \leqq 0.023$ にあるヒー トにつき，T. Fe との関係を，Fig. 5 に示す．LD転炉 では, ソフトブローになるに従い T. Fe は増加するが, 複合吹錬では，底吹きガス流量が増大すると，T. Fe の $L / L_{0}$ への依存性は小さくなる.ソフトブローにしても, T. Fe は約 $10 \%$ に保たれ，底吹きの鋼浴の攪找に対す る寄与が非常に大きいことがわかる.

\section{$4 \cdot 2$ 脱りん反応}

吹止め $\mathrm{P}$ 含有量は，インプット $\mathrm{P}$ 量，スラグ塩基度， スラグ中の T. Fe, および温度により決まる．溶鉄組成， 石灰等の副原料の使用量, 吹止め温度がほほ一定の条件 のもとに，吹止め $[\% \mathrm{P}]$ と T. Fe の関係を Fig. 6 に 示す．底吹きガス流量が増すと，低 T. Fe でも十分な

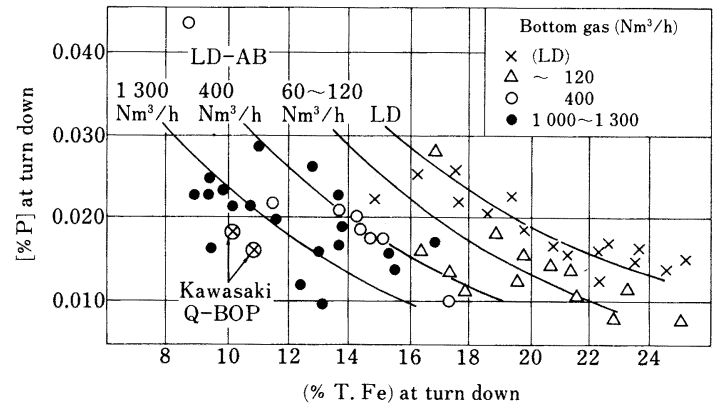

Fig. 6. Influence of the bottom gas flow rate on the relation between $(\% \mathrm{~T} . \mathrm{Fe})$ and $[\% \mathrm{P}]$ at turn down : $70 \mathrm{t}$ combined blow converter ${ }^{1)}$.

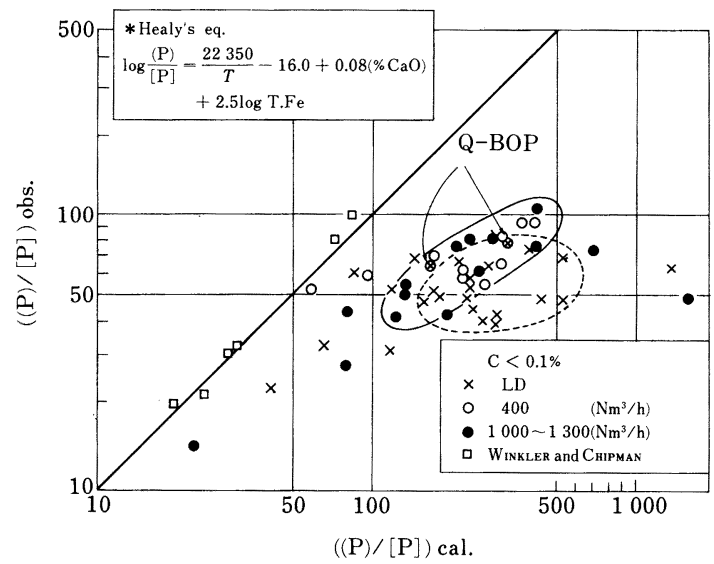

Fig. 7. Comparison of phosphorus partition ratios between calculated and observed values : $70 \mathrm{t}$ combined blow converter ${ }^{1)}$.

脱りんが進行するようになり，Q-BOP の実績值に近づ く、これは, LD 転炉では, 通常, 鋼浴より $50 \sim 100^{\circ} \mathrm{C}$ 高いとされるスラグ温度が，攪拌の強化により低下し， スラグー鋼浴間の $\mathrm{P}$ 分配がより平衡に近づくためと考え られる。

スラグー鋼浴間の $\mathrm{P}$ 分配関係を(1)式で示される Healy の平衡式と比較して, Fig. 7 に示す.

$$
\begin{aligned}
& \log \{(\% \mathrm{P}) /[\% \mathrm{P}]\}=22350 / T-16.0 \\
& +2.5 \log (\% \mathrm{~T} . \mathrm{Fe})+0.08(\% \mathrm{CaO})
\end{aligned}
$$

図より，分配比は Healy の平衡値よりは小さいが，LD 転炉と比べれば，より平衡に近いことがわかる， $250 \mathrm{t}$ 転炉の脱りん挙動を Healy の平衡式を用いて整理した 例 $^{6)}$ を Fig. 8 に示す. LD 転炉では, [\% $\left.\mathrm{P}\right]$ の実績值は Healy の平衡値より大きいが, 複合吹鍊ではほぼ平衡值 と一致している.このように, 複合吹錬効果は炉容積が 大きい方が顕著に現れるようである．脱りん挙動を Healy の平衡式を用いて整理し, 複合吹錬では, その平 


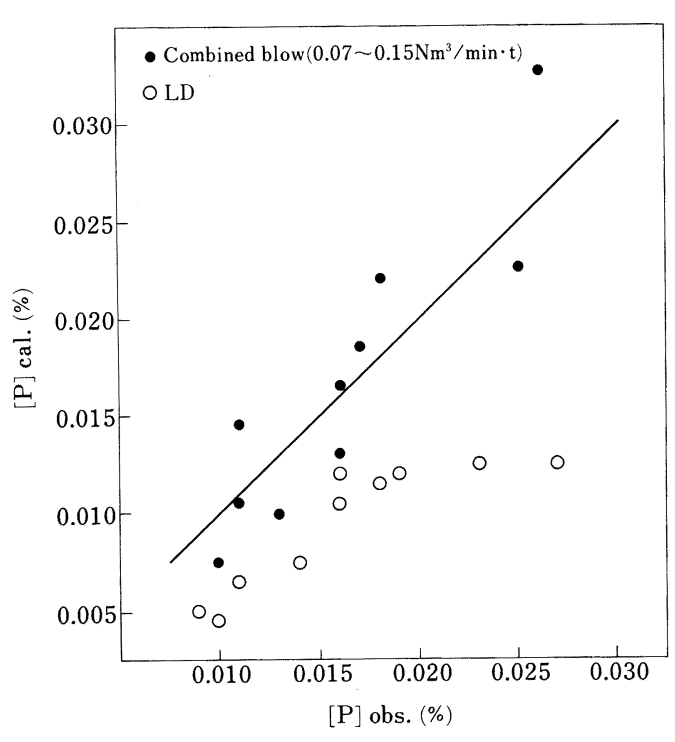

Fig. 8. Comparison of observed $[\mathrm{P}]$ and calculated $[\mathrm{P}]$ based on Healy's dephosphorization equilibrium equation : $250 \mathrm{t}$ converter ${ }^{6}$.

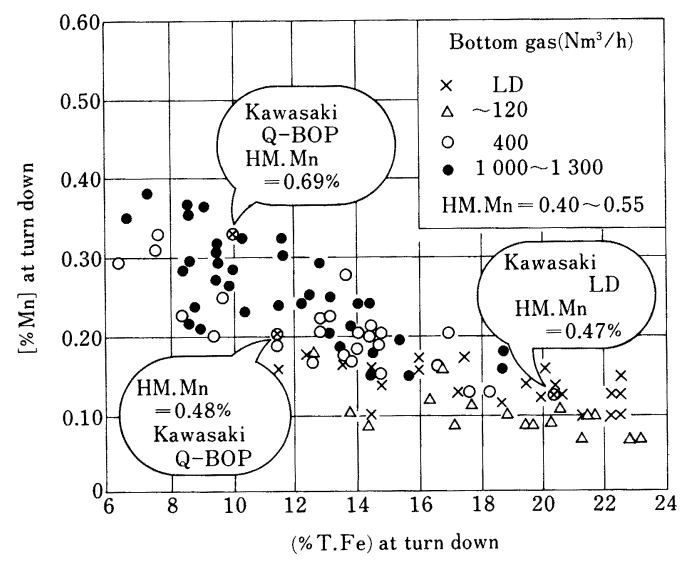

Fig. 9. Relation between (\%T.Fe) and $[\% \mathrm{Mn}]$ at turn down : $70 \mathrm{t}$ combined blow converter ${ }^{1)}$.

衡に近づくという報告は他にもある22).

\section{$4 \cdot 3 \mathrm{Mn}$ 反店}

鋼浴中の $\mathrm{Mn}$ はスラグ中の $\mathrm{FeO}$ により, 次式の反応 で酸化される。

$(\mathrm{FeO})+\mathrm{Mn}=(\mathrm{MnO})+\mathrm{Fe}$

したがって，吹止め $[\% \mathrm{Mn}]$ は，平衡状態では，スラ グ中の T. Fe と反比例の関係にあるはずである. Fig. 9 には, 吹止め $[\% \mathrm{Mn}]$ とスラグ中 T. Fe との関係を示す. 図より, [\% Mn] は, LD 転炉, 底吹き転炉, 複合吹鍊 転炉の別なく, T. Fe に反比例している様子が窅える.
すなわち，Mn 反応では，吹錬様式によらず，ほほ平衡 が成り立っていると考えられる．Fig. 1 において， [\% Mn] は吹錬初期には LD 転炉同様低下寸るが, 中期 で再び増加するのは, T. Fe の低下と鋼浴温度の上昇に よる平衡値の変化に起因している6).また，この中期の Mn の還元反応を利用し，マンガン鉱石を添加すること により，鋼浴中の $\mathrm{Mn}$ 含有量を高めようとする試みも ある ${ }^{23)}$.

\section{5. 脱 炭 挙 動}

尾関らは, $180 \mathrm{t}$ 転炉の複合吹錬において, 脱炭反応 か酸素供給律速から $\mathrm{C}$ 拡散律速に移行する $\mathrm{C}$ 含有量の 底吹きガス流量による变化を調べ，以下のような解析を 行っている ${ }^{24)}$.

上記の臨界 $\mathrm{C}$ 含有量 $[\mathrm{C}]_{T}$, および, 鋼浴循環速度 $C V$ は, 次の $(3)$ 式を変形した $(4)$ 式と, 脱炭速度の台 形モデルに基づく送酸量の式より導かれた $(5)$ 式から求 められる。

$$
\begin{aligned}
& C V \times \frac{[\mathrm{C}]_{T}}{100}=Q \times \frac{k}{1000} \\
& C V=Q \cdot k / 10 \cdot[\mathrm{C}]_{T} \\
& k=\frac{\left([\mathrm{C}]_{T}-[\mathrm{C}]_{L}\right)}{100} \times \frac{W_{M}}{Q_{E}} \\
& \times\left\{\ln \frac{\left([\mathrm{C}]_{T}-[\mathrm{C}]_{L}\right)}{\left([\mathrm{C}]_{E}-[\mathrm{C}]_{L}\right)}-1\right\}+\frac{W_{\mathrm{C}_{0}}}{Q_{E}}
\end{aligned}
$$

ここに, $C V$ は鋼浴循環速度 $(\mathrm{t} / \mathrm{min}), Q$ は送酸速度 $\left(\mathrm{Nm}^{3} / \mathrm{min}\right), k$ は最高脱炭速度 $\left(\mathrm{kg} / \mathrm{Nm}^{3}\right),[\mathrm{C}]_{L}$ は脱 炭限界 $(\%),[\mathrm{C}]_{E}$ は吹止め炭素含有量 $(\%), W_{M}$ は 溶銑質量 $(\mathrm{kg}), W_{\mathrm{C}_{0}}$ は初期炭素量 $(\mathrm{kg}), Q_{E}$ は補正酸 素量 $\left(\mathrm{Nm}^{3}\right)$ である. 式中, $[\mathrm{C}]_{L}$ は $\mathrm{FeO}$ の活量を 1 と 仮定した時の鋼中酸素含有量, および, 鋼中 $[\mathrm{C}] \cdot[\mathrm{O}]$ の関係より得られた， $P_{\mathrm{CO}}$ より求めた。このようにし て求めた $[\mathrm{C}]_{T}$ と $C V$ の底吹きガス流量に対する依存 性を, Fig. 10 に示す. 脱炭の律速段階が酸素供給から 鋼浴中の $\mathrm{C}$ 拡散に移行する臨界の $\mathrm{C}$ 含有量は, 底吹き ガス流量の増加と共に，0.1\%まで低下した。また，鋼 浴循環速度は LD 転炉の 2 倍まで増加した。

\section{6. リンシング効果}

底吹きガスに不活性ガスを用いる場合，上吹き酸素を 止めれば，底吹きガスによるリンシング効果が期待でき る.梅田らは, $250 \mathrm{t}$ 転炉で Ar リンシングを行い, $0.01 \%$ 以下の $\mathrm{C}$ 含有量まで脱炭が可能で, $[\mathrm{C}] \cdot[\mathrm{O}]$ は $P_{\mathrm{CO}}=1$ atm との平衡値まで低下することを示した ${ }^{6)}$. 岸本らは, $180 \mathrm{t}$ 転炉で CO ガスによるリンシングを行い，[\% C ] $\geqq 0.04$ では脱炭が， $[\% \mathrm{C}] \leqq 0.04$ では脱酸が起こるこ とを示した ${ }^{5)}$. 宮脇らは， $250 \mathrm{t}$ 転炉においてリンシン グを行い，Fig. 11 に示すように，温度低下により脱り んが進行することを示した ${ }^{25)}$. 別の報告によれば，そ 


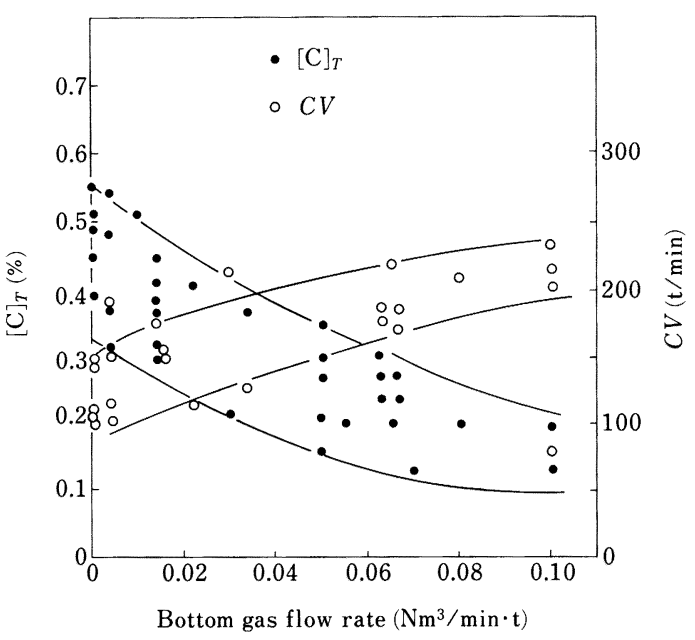

Fig. 10. Changes in critical $[\% \mathrm{C}],[\mathrm{C}]_{T}$, and circulating flow rate of molten steel, $C V$, with the bottom gas flow rate: $180 \mathrm{t}$ combined blow converter $^{23)}$.

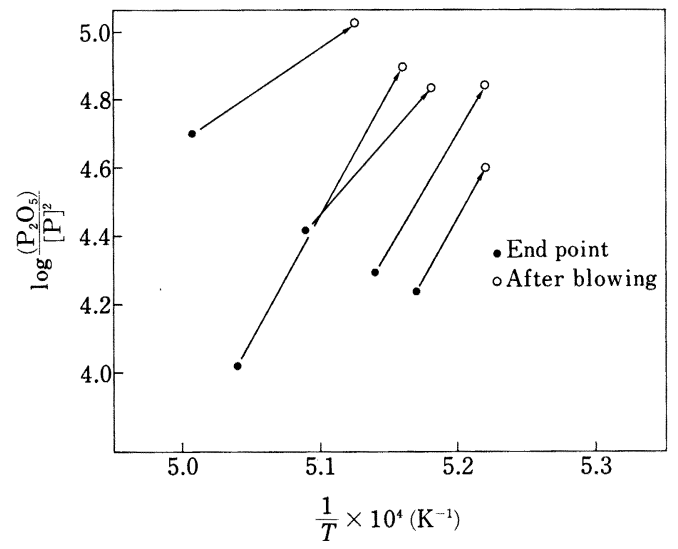

Fig. 11. Relation between $\log \left(\mathrm{P}_{2} \mathrm{O}_{5}\right) /[\mathrm{P}]^{2}$ and $1 / T: 250 \mathrm{t}$ combined blow converter ${ }^{24)}$.

の際, $0.01 \%$ 以下の $\mathrm{P} レ$ レルが容易に得られている ${ }^{26)}$. 岸本らも $5 \mathrm{t}$ 試験転炬で $\mathrm{CO}$ リンシングを行い, 脱りん の進行することを認めている5)

\section{7. 底吹きガスの種類の影響}

底吹きガスとしては, $\mathrm{Ar}, \mathrm{N}_{2}, \mathrm{O}_{2}+\mathrm{C}_{3} \mathrm{H}_{8}, \mathrm{Air}, \mathrm{CO}_{2}$, $\mathrm{CO}$ ，およびそれらの混合ガスが用いられている. $\mathrm{O}_{2}$, $\mathrm{C}_{3} \mathrm{H}_{8}, \mathrm{CO}_{2}$ は以下のように鋼浴と反応することが考え られる.

$$
\begin{aligned}
& 2 \underline{\mathrm{C}}+\mathrm{O}_{2}=2 \mathrm{CO} \\
& \mathrm{C}_{3} \mathrm{H}_{8}=3 \underline{\mathrm{C}}+4 \mathrm{H}_{2}
\end{aligned}
$$

$$
\underline{\mathrm{C}}+\mathrm{CO}_{2}=2 \mathrm{CO}
$$

これらより, $\mathrm{O}_{2}$ と $\mathrm{CO}_{2}$ は吹き込まれてガス流量の 2 倍, $\mathrm{C}_{3} \mathrm{H}_{8}$ は 4 倍の攪䢁効果が期待される. しかし, 高炭域 では（6)，（８）の反応は期待できるものの，低炭域では 鉄の酸化にも使われるため，そのような増大効果は期待

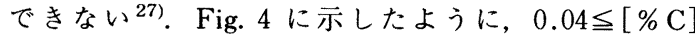
$\leqq 0.06$ では， $\mathrm{O}_{2}$ の攪拌力は $\mathrm{Ar}$ と等価と考えられる ${ }^{1)}$.

$\mathrm{N}_{2}$ は安価なために，Arの代替ガスとして用いられ ている.この際, 吸窒の起こることが懸念されるが, 高 炭域では脱炭が促進され，発生する CO ガスにより， むしろ脱窒が進行する.しかし，吹錬末期には，脱炭効 率が低下し，急激な吸窒が起こる ${ }^{28)}$.

CO ガスも，転炬排ガスを精製すれば安価に得られる ため, Ar の代替ガスとして用いられている。この際, 低炭域では,

$$
2 \mathrm{CO}=\underline{\mathrm{C}}+\mathrm{CO}_{2}
$$

なる反応による加炭の起こることが眯念されるが, 現実 に，加炭は起こっていない5)8). なお，いずれのガスも， 4,5 章で説明した吹止め時の成分挙動および脱炭挙動 に及ぼす効果の観点からは等価である.

\section{8. 底吹きガス流量と喟䢁動力}

Fig. 3，4 に示したように，底吹きガス流量が増すに つれ，治金反応特性は LD 転炉から底吹き転炉のそれ へと移行していく．したがって，どの程度のガス流量を 選ぶかは，鋼種や吹鍊コスト等によって選択される。般には, Table 1 に示したように, 川鉄の K-BOP を除 き4), $0.5 \mathrm{Nm}^{3} / \mathrm{min} \cdot \mathrm{t}$ 以下である. 特に, $\mathrm{O}_{2}$ を吹き込む 場合以外は, 冷却効果があることもあって, 0.2 $\mathrm{Nm}^{3} / \mathrm{min} \cdot \mathrm{t}$ 以下である。 また, 高炭素鋼の吹錬では, 攪找が強化されると， T. Fe が下がりすぎて脱りんに支 障をきたすため, $0.01 \mathrm{Nm}^{3} / \mathrm{min} \cdot \mathrm{t}$ 程度に抑えられてい る $^{22) 26)}$.

底吹きガスの攪拌動力の評価および均一混合時間との 関係は，基本的には，NAKANISHI らにより提案された次 式によっている ${ }^{29)}$.

$$
\begin{aligned}
& \dot{\varepsilon}_{B}\left(28.5 Q_{B} \frac{T}{W}\right) \log \left(1+\frac{H}{148}\right) \\
& \tau=800 \dot{\varepsilon}^{-0.40}
\end{aligned}
$$

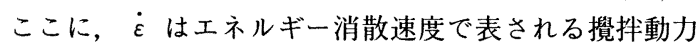
(W/t-steel)， $Q_{B}$ は底吹きガス流量 $\left(\mathrm{Nm}^{3} / \mathrm{min}\right), T$ は 鋼浴温度 $(\mathrm{K}), W$ は鋼浴質量 $(\mathrm{t}), H$ は鋼浴深さ $(\mathrm{cm})$, $\tau$ は均一混合時間 $(\mathrm{s})$ である.（11)式は羽口が 1 本の 場合の式であるが，複数羽口の場合には(12)式のような 修正がなされている4).

$$
\tau=800 \dot{\varepsilon}^{-0.40} N_{t}^{1 / 3}
$$

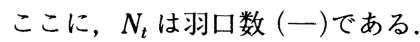

複合吹鍊では，(13)式で示される上吹きガスジェットの 攪找動力も考慮に入れる必要がある。 


$$
\dot{\varepsilon}_{T}=\frac{0.0453 Q_{T} D U^{2} \cos ^{2} \theta}{W \cdot x}
$$

ここに, $Q_{T}$ は上吹きガス流量 $\left(\mathrm{Nm}^{3} / \mathrm{min}\right), D$ はノズル 口径 $(\mathrm{m}), U$ はノズル出口に㧍けるガスの線速度 $(\mathrm{m} / \mathrm{s}), \theta$ はノズル傾斜角 $(\mathrm{deg}), x$ はランス高さ $(\mathrm{m})$ である. 中西らは, 吹き込んだ $\mathrm{O}_{2}$ は $2 \mathrm{CO}$ となること を考慮し, 羽口数 $N_{t}$ およびランスのノズル孔数 $N_{n}$ を 入れて，(10)，(12)，(13)式より，(14)式を得ている4).

$$
\begin{gathered}
\tau=800\left[\left(\frac{57 Q_{B} T N_{t}^{-0.833}}{W}\right) \log \left(1+\frac{H}{148}\right)\right. \\
\left.+\frac{0.0906 Q_{T} D U^{2} \cos ^{2} \theta N_{n}^{-0.833}}{W \cdot x}\right]^{-0.40} \ldots \ldots . .
\end{gathered}
$$

甲斐らは，底吹きガスの攪拌動力および上吹きガスの 攪拌動力として，(15)，(16)式を与えている1).

$$
\begin{aligned}
& \dot{\varepsilon}_{B}=6.18 \frac{Q_{B} \cdot T}{V}\left\{2.3 \log \left(\frac{P+\rho H}{P}\right)+\left(1-\frac{T_{t}}{T}\right)\right\} \\
& \dot{\varepsilon}_{T}=\frac{6.32 \times 10^{-7} \cos \theta}{V} \cdot \frac{Q^{3}{ }_{T} \cdot M}{N_{t}^{2} \cdot D^{3} \cdot x}
\end{aligned}
$$

ここにに $V$ は鋼浴体積, $P$ は大気圧, $\rho$ は鋼浴密度, $T_{t}$ は吹込みガスの初期温度, $M$ は酸素の分子量である. 上吹きガスの攪拌動力の寄与は底吹きガスの $1 / 10$ と見 積もり，総攪拌動力として(17)式を与えている。 また, 均一混合時間の式として(18)式を与えている.

$$
\begin{aligned}
& \dot{\varepsilon}_{S}=\dot{\varepsilon}_{B}+0.1 \dot{\varepsilon}_{T} \\
& \tau=\left(\frac{H}{12.5}\right)^{2 / 3}\left(\frac{\rho}{1}\right)^{1 / 3} \cdot 540 \cdot\left(\dot{\varepsilon}_{B}+0.1 \dot{\varepsilon}_{T}\right)^{-0.5}
\end{aligned}
$$

楠野らは，上吹きガスの攪拌動力には (13)式を用い, 1 本の羽口当たりの底吹きガスの攪挥動力には (10)式を 用い, 3 本の羽口寄与に係数を掛けて, 総攪拌動力を(19) 式で評価している ${ }^{30)}$.

$$
\varepsilon_{e f f}=\varepsilon_{T}+\left(\alpha_{B} \varepsilon_{B}+\alpha_{G} \varepsilon_{G}+\alpha_{D} \varepsilon_{D}\right)
$$

ここに， $\alpha_{j}, \varepsilon_{j}$ は $j$ 羽口に対する係数および底吹きガス の攪找動力である.

これらの式を用いて, 鋼浴の均一混合状態を調べると, 底吹きガスの攪挥効果は，ガス流量が少なくても大きい こと，および底吹きガスの割合が $10 \%{ }^{1)}$ あるいは $20 \%{ }^{4)}$ 以上では，上吹きガスの翼汼効果は無視できるこ とが明らかとなった。

なお, 最近では, 底吹きガスの有効攪拌動力 $\dot{\varepsilon}_{M}(\mathrm{~W} / \mathrm{t})$ の式として，森·佐野による次式 ${ }^{31)}$ がよく用いられてい るようである。

$$
\begin{aligned}
\dot{\varepsilon}_{M} & =\frac{0.0142 V_{g} T_{l}}{M_{l}}\left[\log \left(1+\frac{h_{0}}{1.46 \times 10^{-5} P_{2}}\right)\right. \\
& +\frac{\eta}{2.303}\left\{\frac{T_{n}}{T_{l}} \ln \frac{P_{n}}{P_{1}}+\left(1-\frac{T_{n}}{T_{l}}\right)\right. \\
& \left.\left.+\frac{T_{n}}{P_{n} T_{l}}\left(\frac{1}{2} \rho_{g n} U_{n}^{2}\right)\right\}\right] \ldots \ldots \ldots \ldots \ldots \ldots \ldots
\end{aligned}
$$

ここで， $V_{g}$ はガス流量 $(\mathrm{Nl} / \mathrm{min}), M_{l}$ は溶体質量 $(\mathrm{t})$, $T_{l}, T_{n}$ は溶鉄, ガス (ノズル出口) の温度 $(\mathrm{K}), P_{1}$, $P_{n}$ はノズル出口における静水圧, ガス圧力 $(\mathrm{Pa}), P_{2}$ は浴表面の雲囲気压力 $(\mathrm{Pa}), \rho_{g n}, U_{n}$ はノズル出口の ガス密度 $\left(\mathrm{kg} / \mathrm{m}^{3}\right)$, 速度 $(\mathrm{m} / \mathrm{s})$, および $\eta$ はガスが持 つエネルギーのうち浴内循環流動に有効に使われる割合 である.

\section{9. 冶金反応特性指標}

Y. KAто らは，底吹き転炉の吹鍊特性の指標として， (20)式で示す ISCO (Index of Selective Carbon Oxidation) 值なる指標を提案した ${ }^{32)}$.

$$
\operatorname{ISCO}=\left\{\frac{2 Q_{O}}{\left(2 Q_{\mathrm{O}}+Q_{d}\right)}\right\}\left\{\frac{Q_{\mathrm{O}}}{W / \tau}\right\}
$$

ここに， $Q_{\mathrm{O}}$ は全酸素流量 $\left(\mathrm{Nm}^{3} / \mathrm{min}\right) ， Q_{d}$ は希釈して $\mathrm{CO}$ 分圧を下げる $\mathrm{Ar}, \mathrm{N}_{2}$, あるいは羽口冷却剂の分解 発生ガスの流量 $\left(\mathrm{Nm}^{3} / \mathrm{min}\right)$ である. 右辺の第 1 項は $P_{\mathrm{CO}}$ に相当する項であり，第 2 項は送酸速度と鋼浴の 循環速度の比に対応する項と考えられる.中西らは, (21) 式を複合吹錬転炉に適用するために，(22)式のように変 形した4).

$$
\mathrm{ISCO}=\left\{\frac{2(\beta+1)}{2(\beta+1)+4 \gamma}\right\}\left\{\frac{Q_{\mathrm{O}}}{W / \tau}\right\}
$$

ここに, $\beta=q_{\mathrm{O}_{2}}^{T} / q_{\mathrm{O}_{2}}^{B}, \gamma=q_{P r} / q_{\mathrm{O}_{2}}^{B}, q_{\mathrm{O}_{2}}^{T}$ は上吹き酸素流 量 $\left(\mathrm{Nm}^{3} / \mathrm{min}\right), q_{\mathrm{O}_{2}}^{B}$ は底吹き酸素流量 $\left(\mathrm{Nm}^{3} / \mathrm{min}\right), q_{P r}$ はプロパン流量 $\left(\mathrm{Nm}^{3} / \mathrm{min}\right), Q_{d}=4 q_{P r}$ である. 中西ら は, (22)式の ISCO 值が, Table 2 に示すように, LD 転炉，LD-KG，K-BOP，底吹き転炉の順に減少し，そ れに対応して T. Fe も減少しており, 鋼浴の酸化度が ISCO 值とよく対応していることを示した4).

甲斐らは, $\mathrm{FeO} の$ 生成速度を決める送酸速度, 鋼浴 の循環速度, $\mathrm{FeO}$ を還元する $\mathrm{C}$ の供給速度のバランス をあたえる指標として, BOC (Balance of Oxygen-and Carbon-feeding rate）を(23)式のように定義した1).

$$
\mathrm{BOC}=\frac{Q_{\mathrm{O}_{2} \mathrm{~S}}}{(W / \tau) \cdot[\% \mathrm{C}]}
$$

ここに， $Q_{\mathrm{O}_{2} \mathrm{~S}}$ は上吹き酸素流量と底吹き酸素流量の総 和である. $0.02 \leqq[\% \mathrm{C}] \leqq 0.20$ の広い $\mathrm{C}$ 域における $\mathrm{T}$. $\mathrm{Fe}$ と BOC の関係を, Fig. 12 に示す. BOC は送酸速 度の差を包括し, 反応系の酸化度を表す T. Fe を支配 する指標となることがわかる.

なお，鋼浴の循環流動の目安となる均一混合時間も一 つの指標と考えられるが, 甲斐らによれば, これだけで

Table 2. ISCO value and T. Fe in different process.

\begin{tabular}{c|rccc}
\hline & LD & LD-KG & K-BOP & Q-BOP \\
\hline ISCO & 225 & 130 & 64 & 58 \\
T. Fe at $0.05 \% \mathrm{C}$ & 20 & 18 & 13 & 10 \\
\hline
\end{tabular}




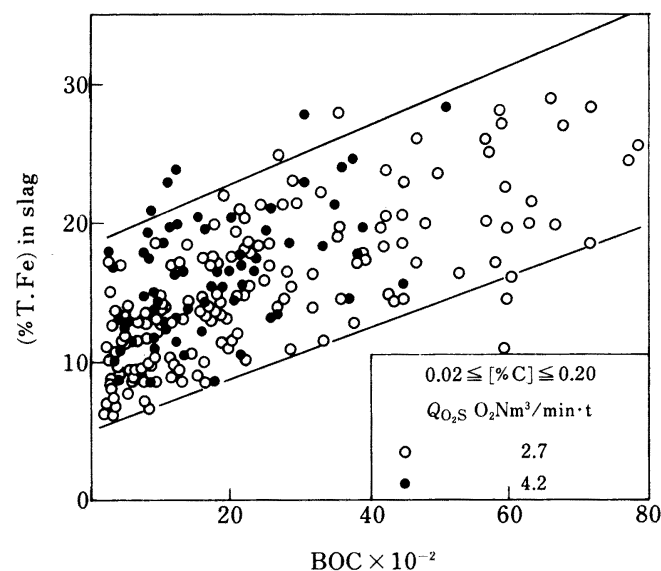

Fig. 12. Relation between BOC and (\%T.Fe) in slag : $70 \mathrm{t}$ combined blow converter ${ }^{1)}$.

は複合吹鍊の治金反応特性を表すには不十分のようであ る1). しかし，そのよjな検討はなされていないものの， 前出の (4), (5)式の方法で求められた鋼浴循環速度 $C V$ は一つの指標となり得るかもしれない。

\section{0. 眖珪·脱りん鉄を用いた少量スラグ吹鍊}

最近は, 溶銑予備処理により脱硫, 脱珪, 脱りんを行 い，転炉では脱炭と昇温のみが行われている，その時の 複合吹鍊はどう変化するかを以下に解説する。

Fig. 13 に，240 $\mathrm{t}$ 転炉において，底吹きガス流量 $0.06 \sim 0.10 \mathrm{Nm}^{3} / \mathrm{min} \cdot \mathrm{t}$, 生石灰原単位 $8 \mathrm{~kg} / \mathrm{t}$ の条件下 で吹錬した時の，各成分の推移を示す ${ }^{33)}$. 脱炭は吹錬 初期から最盛期に入り，低炭域まで停滞が見られない。

Fig. 14 に, 脱炭が酸素供給律速から C の拡散律速に移 行する臨界炭素含有量のプロセスによる違いを示す。

LD, 複合吹錬・通常スラグ, 複合吹鍊・少量スラグの順 に臨界炭素含有量は低下した。しかも，そのばらつき幅 も小さくなった。このように, 少量スラグの複合吹鍊で は，より脱炭が優先されることがわかる.

Fig. 15 には， $300 \mathrm{t}$ 転炉での吹止め C と T. Fe の間 の関係を示す ${ }^{35)}$. 少量スラグの複合吹錬では, T. Fe が 通常の複合吹錬よりかなり高くなり, LD 転炬のレベル まで上がっている。しかし，吹錬末期に上吹き送酸速度 を約 $2 / 3$ に減少することにより，通常の複合吹錬のレ ベルまで下げることができた。 スラグ量が少ないことを 考えれば，鉄歩留りは，かなり，改善された，鉄歩留り を考える場合，ダストロスも考慮しなければならな ( ${ }^{33)}$. 少量スラグ吹鍊では, 従来法と比べ $2 \mathrm{~kg} / \mathrm{t}$ 相当 の排ガス中へのダストロスの増加があった。これを抑制 するためには, 少量のカバースラグを確保するか, $L / L_{0}$ を下げた超ソフトブロー化が必要である． $L / L_{0}$

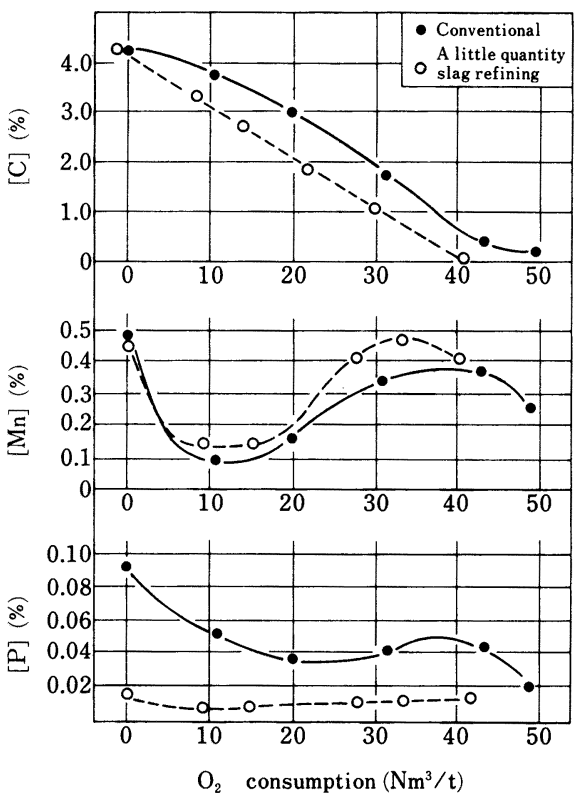

Fig. 13. Changes in $[\mathrm{C}],[\mathrm{Mn}]$ and $[\mathrm{P}]$ during blowing in less slag operation : $240 \mathrm{t}$ combined blow converter $^{31}$ )
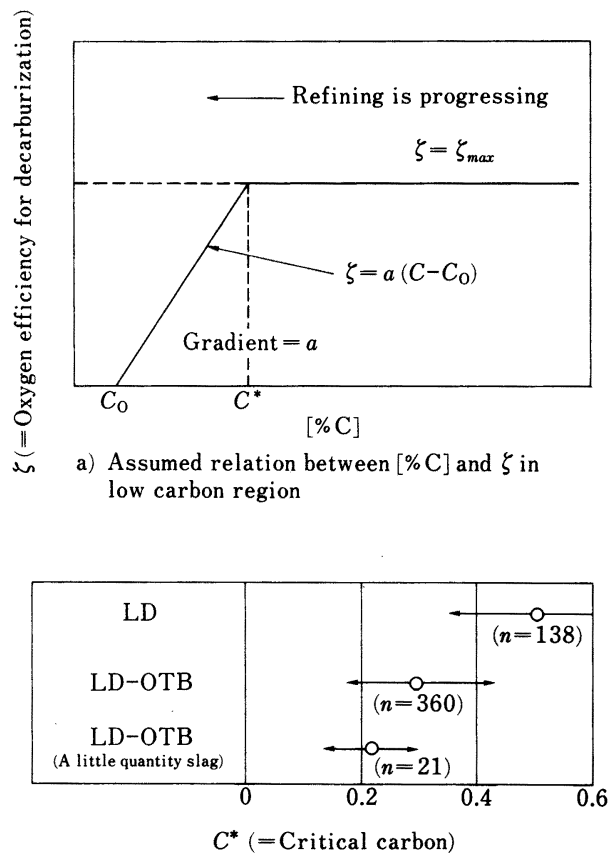

b) Difference of $C^{*}$ for each blowing methods

Fig. 14. Changes in critical carbon content by different operations : $240 \mathrm{t}$ converter ${ }^{31)}$. 


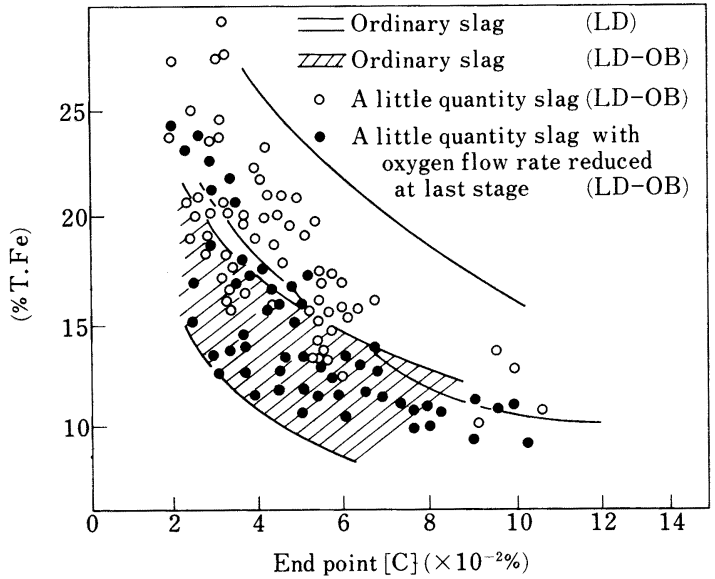

Fig. 15. Relation between (\%T.Fe) and [C] at end point : $300 \mathrm{t}$ converter ${ }^{32)}$.

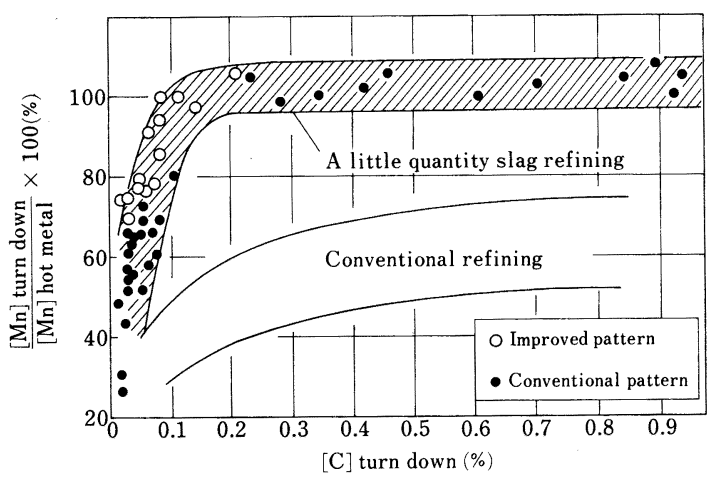

Fig. 16. Comparison of $\mathrm{Mn}$ yield for less slag blowing to that for conventional blowing : $240 \mathrm{t}$ converter ${ }^{31)}$.

を 0.2 以下にすることにより, 従来吹錬並みか, $1 \mathrm{~kg} / \mathrm{t}$ のダストロスの低減が可能となった.

Mn の挙動は, Fig. 13 に示すように, 従来と同様の 隆起が見られるが，初期 $[\% \mathrm{Mn}]$ に対する $[\% \mathrm{Mn}]$ の極大 值の比が 1.0 に近くなる ${ }^{33)}$. Fig. 16 に, Mn 歩留りと 吹止め $[\% \mathrm{C}]$ の関係を示す ${ }^{33)}$. 少量スラグ吹鍊では, 著しく Mn 歩留りの改善が見られ，高炭域では $100 \%$ に近い Mn 歩留りが得られている.一方, 臨界 [\% C ] 以下では Mn の酸化が急激に進む。これを抑制するた めに, 臨界 $[\% \mathrm{C}]$ 以下の低炭域で, 上吹き送酸速度を 減少し，底吹きガス流量を増加した。これにより，低炭 域でも, 約 $70 \%$ の $\mathrm{Mn}$ 歩留りが得られた。この他にも, 種々の吹鍊条件の改善により， [C]=0.06\% で $60 \%$ の $\mathrm{Mn}$ 歩留りを得たという報告もある ${ }^{34)}$. さらに，添加さ れたマンガン鉱石の還元により, $1.00 \%$ 以上の高 $\mathrm{Mn}$

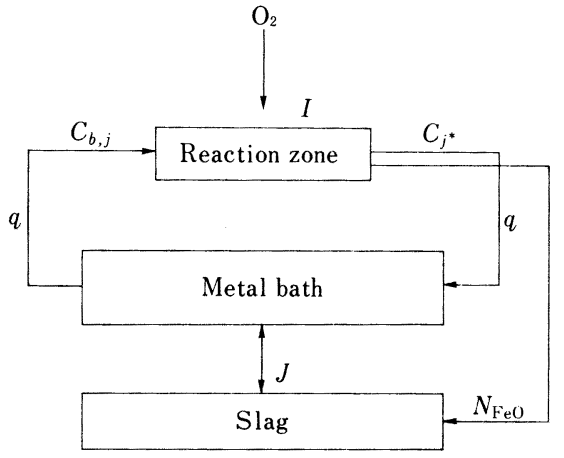

Fig. 17. Illustration of reaction model ${ }^{36)}$.

吹止めが可能となった ${ }^{33)}$.

鋼中 $\mathrm{H}$ は，転炉副原料や合金鉄から持ち込まれる水 分に大きく依存している，少量スラグ吹錬では，造滓材 の生石灰原単位が小さいことと, 高 $\mathrm{Mn}$ 歩留りにより 合金鉄の添加量が少なくてすむことから，鋼中 $\underline{H}$ を低 レベルに抑えることができる30).

\section{1. [C]・[0] と平衡する $P_{\mathrm{CO}}$ が $1 \mathrm{~atm}$ 以下になる理由}

底吹き転炉や複合吹錬転炉では，吹錬末期に $[\mathrm{C}] \cdot[\mathrm{O}]$ と平衡する $P_{\mathrm{CO}}$ が $1 \mathrm{~atm}$ 以下になる，当初，その理由 は $\mathrm{C}_{m} \mathrm{H}_{n}$ 等の底吹き羽口冷却ガスや底吹きガスによる $P_{\mathrm{CO}}$ の希釈効果と考えられていた ${ }^{6) 20)}$. しかし, 底吹き ガスに CO を用いても同様な効果があることが明らか にされ5)，希釈説では説明がつかないことがわかっ た。これに対し，低炭域の [O] はスラグ中の酸素ポテ ンシャルにより決まることを定性的にのべた報告があ $3^{36)}$-38). 最近, 岸本らは $P_{\mathrm{CO}}$ や底吹きガス流量を広 範囲に変えた実験により，以下のような反応モデルによ り，定量的な説明を与えている ${ }^{39)}$.

Fig. 17 に, 反応モデルの模式図を示す. 転炉内を酸 素ジェットの当たる反応带, 鋼浴本体, スラグの三つの 部分に分ける. そして, 以下のような仮定を置く.

1 ）反応帯に流入した濃度 $C_{j, b}$ の溶鋼は, 酸素ジェッ トからの酸素とただちに反応して平衡状態に達し， $C_{j} *$ として反応帯から排出される.

2 ) 排出された溶鋼は浴本体中の各成分と完全に混合 された後，再び反応帯に循環する.

3 ）反応帯の体積は鋼浴に比べて十分小さく, 反応帯 での各成分の蓄積は無視できる.

4 ) 鋼浴本体の混合状態は完全混合である.

5 ）反応帯では大量の酸素が供給されているため, $a_{\mathrm{FeO}}$ は常に1である.

6 ) 供給酸素のうち脱炭と鋼浴の酸素濃度の上昇に使 用される以外の酸素は酸化鉄 $(\mathrm{FeO})$ を生成し, スラグ 
に蓄積される。この時，鋼浴本体とスラグの間には，そ れぞれの $P_{\mathrm{O}_{2}}$ の差によって酸素の移行が生じる.これ らの仮定の基に，各成分濃度の変化式㧍よび物質収支の 式を導くと，以下のようになる。

$$
\begin{aligned}
& W\left(d C_{\mathrm{O}, b} / d t\right)=q\left(C_{\mathrm{O}} *-C_{\mathrm{O}, b}\right)+J\left(C_{\mathrm{O}} * *-C_{\mathrm{O}, b}\right) \\
& \text {................................(24) } \\
& W\left(d C_{\mathrm{C}, b} / d l\right)=q\left(C_{\mathrm{C}^{*}}-\gamma_{\mathrm{C}, \mathrm{b}}\right) \\
& \left(W_{s} / 100\right)\left(d C_{\mathrm{FeO}, b} / d t\right)=N_{\mathrm{FeO}}-\left(C_{\mathrm{FeO}, b} / 100\right) \text {. } \\
& d W_{s} / d t+(71.9 / 16) \cdot(1 / 100) \cdot J\left(C_{\mathrm{O}, b}-C_{\mathrm{O} * *}\right) \\
& q\left(C_{\mathrm{C}, b}-C_{\mathrm{C}^{*}}\right)=I\left(C_{\mathrm{C}^{*}}-C_{\mathrm{C}, e}\right) \\
& q\left(C_{\mathrm{O} . b}-C_{\mathrm{O}^{*}}\right)=I\left(C_{\mathrm{O}^{*}}-C_{\mathrm{O}, e}\right) \\
& N_{\mathrm{FeO}}=(71.9 / 11.2) Q+(71.9 / 16) \cdot(1 / 100) I \cdot \\
& \left(C_{\mathrm{O}^{*}}-C_{\mathrm{O}, e}\right)-(71.9 / 12) \cdot(1 / 100) \cdot I\left(C_{\mathrm{C}^{*}}-C_{\mathrm{C}, e}\right)
\end{aligned}
$$

ここに, $W$ は溶鋼質量 $(\mathrm{kg}), q$ は循環している溶鋼の 質量流量 $(\mathrm{kg} / \mathrm{min}), J$ はスラグーメタル間の酸素の物質 移動速度を決定する因子 $(\mathrm{kg} / \mathrm{min}), N_{\mathrm{FeO}}$ は反応帯にお ける $\mathrm{FeO}$ の生成速度 $(\mathrm{kg} / \mathrm{min}), W_{s}$ はスラグ質量 $(\mathrm{kg})$, $C_{j, b}$ は鋼浴本体あるいはスラグの $j$ 成分の濃度 $(\%)$, $C_{j}$ * は反応带での $j$ 成分の濃度 $(\%), C_{O} * *$ はスラグの $a_{\mathrm{FeO}}$ に平衡する酸素濃度 $(\%), C_{\mathrm{O}, e}$ は $a_{\mathrm{FeO}}=1$ と平衡 する酸素濃度 $(\%), C_{\mathrm{C}, e}$ は $C_{\mathrm{O}, e}$ および $P_{\mathrm{CO}}$ と平衡する 炭素濃度 $(\%), I$ は反応帯における混合の程度を表す因 子 $(\mathrm{kg} / \mathrm{min}), Q$ は送酸速度 $\left(\mathrm{Nm}^{3} / \mathrm{min}\right)$ である.

各平衡濃度は文献值から求める。 $q, J, I$ はパラメー ターであるが, $q$ は均-混合時間との関係より決定し, $J$ と $I$ に比例関係を仮定し, $I$ をパラメーターとして数 值計算を行い, 脱炭酸素効率と [\% C ] の関係が各転炉 に损ける実測值と対忍するようにIを決定した。その 結果を基に，Q-BOP, K-BOP および LD-KGCにおけ る $[\% \mathrm{C}]$ と $[\% \mathrm{O}]$ および $\mathrm{T} . \mathrm{Fe}$ との関係を計算した ところ, 実測值とよく対応した。このことより, 吹鍊末 期に打いて, 炉内の $P_{\mathrm{CO}}$ との平衡値よりも低い值まで 脱炭, 脱酸反応が進行する理由は以下のように説明され る.

強攪找条件下では, 反応帯での脱炭反応速度が増大す るために，反応带での $\mathrm{FeO} の$ 生成が抑制される．酸素 は，おもに，脱炭と鋼浴中の酸素濃度を高めるのに使わ れ, 反応带では, $a_{\mathrm{FeO}}=1$ と平衡する酸素, 炭素濃度 まで反応が進行する。一方, スラグ相の $\mathrm{FeO}$ 濃度は $a_{\mathrm{FeO}}=1$ と平衡する濃度までは上がらず，そのために， 低炭素濃度域までスラグ中の $\mathrm{FeO}$ 濃度が低くなる。そ の結果, スラグ相の酸素ポテンシャルは鋼浴本体よりは 低くなる．したがって，スラグーメタル界面では，むしろ， スラグによる脱酸が進行する。この脱酸効果は, メタル とスラグの酸素ポテンシャルの差が大きいほど大きい. スラグの $\mathrm{FeO}$ 濃度が低くなる強揁拌の場合ほど，また， メタルの酸素ポテンシャルが急激に上昇する低炭素濃度
域になるほど，脱酸効果が大きくなる.

このように，複合吹鍊では，強穓找による優先的脱炭 が低炭域まで進行することが [C] ・ [O] 関係や T. Fe を決定する要因となっていると考えられる。

\section{2. 結言}

複合吹鍊の治金反応特性をまとめると，底吹きガスの 攪拌により，極低炭域まで脱炭が優先され，スラグの酸 素ポテンシャルは低く抑えられ，また，スラグーメタル 間反応はより平衡に近づき，高 $\mathrm{Mn}$ 歩留りと，スラグ 中の T. Fe が低いにもかかわらず，LD 転炉並みの脱り んが達成された，ということになろう。しかも，このよ うな効果が, 上吹き送酸速度の 10 分の 1 以下の底吹き ガス流量で得られたことが, 複合吹鍊を今日の隆盛に導 いた一つの要因であると考えられる，さらに，その後の 溶鉄予備処理技術の完成とあいまって，種々の製鍊機能 の拡大へと発展してきた訳である.

最後に，本解説をまとめるにあたり，貴重な資料を提 供された鉄鋼各社に，感謝の意を表す。また，有益なコ メントをいただいた, 名古屋大学 材料プロセス工学科 の浅井滋生教授および本特集号編集委員各位に謝意を表 す。なお，提供された資料をはじめ，本稿に関連する資 料は膨大な数にのぼるので，そのすべてを網羅すること はせず，解説に必要な文献を例示する形をとったことを お断りする.

\section{文献}

1) 甲斐 幹, 大河平和男, 平居正純, 村上昌三, 佐藤宜雄: 鉄と鋼, 68 (1982), p. 1946

2 ) 甲谷知勝, 工藤和也, 村上昌三, 沖森真弓, 中島坋生, 磯村福義: 鉄と銅, 67 (1981), S 10

3 ) $K$. Taguti, $M$. Hanmyo, $Y$. Shiratani and $T$. Hasegawa: Iron Steel Eng., 60 (1983) Apr., p. 26

4 ) 中西恭二, 斉藤健志, 野崎 努, 加藤嘉英, 鈴木健一郎, 江見俊彦: 川崎製鉄技報, 15 (1983)，p. 100

5 ) 岸本康夫, 加藤嘉英, 桜谷敏和, 藤井徹也, 山田純夫, 大宮 茂: 川崎製鉄技報, 21 (1989), p. 168

6 ）梅田洋一, 増田誠一, 多賀雅之, 姉崎正治, 平田武行: 住友金属, 32 (1980), p. 264

7 ) 喜多村実, 副島利行, 伊東修三, 安井 勉, 松井秀雄, 林 努: 鉄と鋼，66（1980)，S827

8 ) 副島利行, 小林潤吉, 松本 洋, 松井秀雄, 藤本英明, 中根義信，源間信行：鉄と鋼，71（1985), S 989

9 ) $H$. Takahashi, $T$. Okimura, $F$. Hoshi and $Y$. Miyagawa: Steelmaking Proceedings, 69 (1986), p. 587

10）成田貴一, 富田昭津, 片桐 望, 喜多村実, 川崎正蔵, 金塚奉夫: 鉄と鋼, 63 (1977), A87

11) M. Kawakaml, $K$. S. Goto and M. Matuoka: Metall. Trans. B, 11 (1980), p. 463

12) H. Koamider, $H$. Neuhaus and H. SchencK: Stahl Eisen, 77 (1957), p. 1277

13) 加藤 健, 今井純一, 藤原和彦: 鉄と鋼, 48 (1962), p. 465

14) Von B. Kalling: Stahl Eisen, 73 (1953) 23, p. 1446

15）成田貴一, 富田昭津, 小山伸二, 伊藤孝道, 広岡康雄: 鉄と鋼，55（1969), p. 959 
16）渡辺章三，大石持司，山本志郎，石橋政衛: 鉄と鋼，47 (1961), p. 355

17) E. Shurann, C. G. Mahn, J. Schoop and W. Resch: Stahl Eisen, 97 (1977) 22, p. 1069

18) F. E. Rote and R. A. FlinN: Metall. Trans., 3 (1972), p. 1373

19）永田和宏, 中西恭二, 数土文夫, 後藤和弘: 鉄と鋼, 68 (1982), p. 277

20）中西恭二, 三本木貢治: 鉄と鋼，65 (1979), p. 138

21）村上昌三, 大河平和男, 吉井正孝, 有馬慶治, 村上義男: 製鉄研究 (1984) 315 , p. 71

22）喜多村実, 小山伸二, 伊東修三, 松井秀雄, 広瀬 勇: 鉄と鋼, 66 (1980), S 828

23）喜多村実, 小山伸二, 伊東修三, 松井秀雄, 大神正彦, 西村哲臣: 鉄と鋼, 66 (1980), S 829

24）尾関昭矢, 長谷川輝之, 丹村洋一, 江種俊夫, 碓井 務, 山田健三: 鉄と鋼，67 (1981), S 269

25）宮脇芳治, 白谷勇介, 半明正之, 長谷川輝之, 丹村洋一, 石川博章: 鉄と鋼, 68 (1982), S 901

26) Y. Miyawaki, $Y$. Nimura, $T$. Usui, $K$. Yamada and $T$. HIROSE: Mix Gas Blowing (1984), p. 163

27）大西正之, 武 英雄, 奥田治志, 山田博右, 大図秀志, 永井 潤: 鉄と鋼, 69 (1983)，S 1015

28）副島利行, 斉藤 忠, 松本 洋, 星川郁生: 鉄と鋼, 70 (1984), S 892
29) K. NaKanishi, $T$. FuJII and J. Szekely: Ironmaking Steelmaking, 3 (1975), p. 193

30）楠野春彦, 重松直樹, 小林芳夫, 栗原健郎, 星野和夫, 近間次雄: 日新製鋼技報（1988） 59, p. 34

31）森一美, 佐野正道: 第 $122 \cdot 123$ 回西山記念技術講座 （日本鉄銅協会編）（1988）, p. 158

32) $K$. KaTo, $N$. NAKANISHI and T. NoZAKI: Japan-Sweden Joint Symposium on Ferrous Metallurgy（1978 年 12 月）

33）木村雅保, 松井秀夫, 伊東修三, 斉藤 忠, 副島利行, 喜多村実: 鉄と鋼, 69 (1983), p. 1893

34）山崎 勲, 青木伸秀, 渡辺吉夫, 丸川雄净, 城田良康, 興梠昌平: 鉄と鋼, 73 (1987), S 217

35) 木内啓翤, 石渡信之, 中村晧一, 奥村治彦, 藤井秀敏: 鉄と鋼, 70 (1984), S 248

36) 碓井 務, 山田健三, 宮下芳雄, 丹村洋一, 長谷川輝之: 学振 19 委-No. 10340 (昭和 56 年 5 月)

37）大河平和男, 田中 新, 平居正純: 融体精錬反応の物理化 学とプロセス工学（鉄鋼基礎共同研究会融体精鍊反応部 会編）（1985）, p. 245

38）平田武行, 丸川雄净, 戸崎泰之, 姉崎正治: 鉄と鋼, 70 (1984), S 891

39）岸本康夫, 加藤嘉英, 桜谷敏和, 藤井徹也: 鉄と鋼, 75 (1989), p. 1300 